\title{
THROUGH A GLASS DARKLY: BRITISH REPRESENTATIONS OF THE POLISH-LITHUANIAN UNION IN THE LATE-16TH AND 17TH CENTURIES*
}

\author{
Anna Kalinowska \\ (Tadeusz Manteuffel Institute of History, Polish Academy of Sciences)
}

ABSTRACT The article discusses how post-1569 relations between Poland and the Grand Duchy of Lithuania were presented in various written materials produced in Britain in the late-16th and 17th centuries. It analyses both the materials produced by and for the court or professional elites, and widely circulating publications (books and newspapers) which were readily available to the general reading public. It argues that there is strong evidence that British readers were aware of the existence of the Polish-Lithuanian Union, although the union itself was rarely presented either accurately or in any detail. They therefore had a very blurred conception of how it functioned in practice, as can be illustrated, for example, by British authors downplaying or simply denying the fact that after the Union of Lublin Lithuania became a constituent part of the Commonwealth with a status equal to that of Poland. Moreover, few writers and editors considered it necessary to provide readers with a proper explanation of the union's basic 'rules of engagement', or any reflections on how it functioned on an organisational level.

KEYWORDS: Grand Duchy of Lithuania, Poland, 17th-century Britain, PolishLithuanian Union, representations, perception.

\section{In 1575, the Venetian diplomat Girolamo Lippomano presented} the Senate of La Serennissima, as was required of him, with a Relazione of his recently completed mission to Poland-Lithuania. ${ }^{1}$ He was given no room for creativity: the report had to follow

* The research for this article was partly funded by the National Science Centre (the project 'Rzeczpospolita Obojga Narodów w rękopiśmiennym obiegu informacji w Anglii w pierwszej połowie XVII w. Informacje o Polsce w newsletterach Johna Pory'ego', MINIATURA, 2018-2019, IH PAN)

${ }^{1}$ G. Lippomano, 'Relazione di Polonia di Girolamo Lippomano 1575', in: Relazioni degli ambasciatori Veneti al senato, Vo l14, ed. E. Albèri (Cambridge, 2012), pp. 273-316. 
a standard structure and cover a number of issues, such as a geographical description of the state in question, its customs, relations with its neighbours, its economic and military potential, the ruler himself, and, of course, its political system. As a result, a Relazione often showed an uncanny resemblance to the reports written by ambassadors who had earlier worked in the same country. ${ }^{2}$ In this particular case, Lippomano faced an additional and serious challenge, which made it impossible for him to simply update materials which already existed: he was the first Venetian ambassador to visit Cracow since the Union of Lublin was agreed in 1569 , and in the light of the new political reality that resulted from the death of Sigismund Augustus, the last monarch of the Jagellonian dynasty in the direct male line. Therefore, he had to present his superiors with a reconfigured picture of what used to be the Jagiellonian monarchy, but which had now become the Polish-Lithuanian Commonwealth.

Despite referring to the 'kingdom of Poland' as the subject of that text in the final sentence of his report, ${ }^{3}$ it should be acknowledged that Lippomano performed rather well when it came to recognising the dual character of the Commonwealth. For example, when describing the country's territory, he singled out Poland and Lithuania as equally important, by indicating their status as two superior constituent parts of the state, and categorising all others simply as le altre provincie sottoposte a quel regno. ${ }^{4} \mathrm{He}$ also emphasised that in both Poland and the Grand Duchy of Lithuania, there existed a number of offices that were exactly the same (marshals, chancellors, vice-chancellors, treasurers), and which mirrored one another. ${ }^{5}$ Finally, Lippomano pointed out that the union of 1569 had resulted partly from the fact that Sigismund Augustus had not produced an heir, which had profound consequences for the Poles and the Lithuanians, and its key element was the unification of

${ }^{2}$ F. De Vivo, 'How to Read Venetian Relazioni', in: Renaissance and Reformation, Vol. 34, Nos 1-2 (2011), pp. 25-59; D.E. Queller, 'The Development of Ambassadorial Relazioni', in: Renaissance Venice, ed. J.R. Hale (London, 1973), pp. 174-196.

${ }^{3}$ Lippomano, 'Relazione', p. 316.

${ }^{4}$ Lippomano, 'Relazione', pp. 275, 28o.

${ }^{5}$ Lippomano, 'Relazione', pp. 286-287. 
the political system by extending privileges enjoyed by the Polish nobility to the nobility of the Grand Duchy of Lithuania. ${ }^{6}$

As can be seen, the Venetian ambassador managed to identify accurately some of the key elements that were at the core of the relationship between Poland and the Grand Duchy in the post1569 period. But Lippomano was not alone. Similar attempts to explore the realities of the Polish-Lithuanian Union and to present them either to various groups of the public or individuals, were undertaken by other diplomats, academics, writers and politicians, or simply private individuals throughout Europe who, for some reason, happened to wish or need to elaborate on this issue in some form. Similarly, in keeping with the development of the printing market and news media, and as information about and from Poland-Lithuania became more easily accessible to the European reading public, events such as subsequent elections and wars, especially with the Ottoman Empire and Sweden, sparked people's interest in the Commonwealth.

Therefore, information on how the union was established, its main characteristics and how it worked, was very much present in Europe's knowledge and information transfer systems. However, from what is known about these systems, it can be argued that, at least initially, the materials which provided information on the functioning of Poland-Lithuania, and which were therefore a basis for the foreign representations of the union, may in many instances have been rather limited and repetitive. Moreover, the information itself, unlike Lippomano's report, was often misleading, because it did not accurately present the key facts about the union. This was particularly true with regard to countries such as Britain. Although it is clear that the reading public there was very much aware of Poland-Lithuania's existence and its role in East-Central Europe, ${ }^{7}$ and there were a number of ways information on and news from the Commonwealth were disseminated in England, and

${ }^{6}$ Lippomano, 'Relazione', pp. 280-282.

${ }^{7}$ A. Kalinowska, “Kingdome differing from other in Europe...” Rzeczpospolita Obojga Narodów w siedemnastowiecznych tekstach anglojęzycznych", in: Studia Historyczne, Vol. 6o, No 4 (240), (2017), pp. 25-45. 
also probably in Scotland, ${ }^{8}$ it cannot be said that the fact that it was a composite state shaped the way it was perceived in Britain. ${ }^{9}$

This, however, did not prevent some historians from arguing that, for the British, the Polish-Lithuanian state's federalist form was one of the main factors that singled out Poland-Lithuania among other European states, and that the English and Scots had sufficiently detailed knowledge of the union between Poland and the Grand Duchy of Lithuania that it could be reckoned a possible model for the union(s) between England and Scotland. ${ }^{10}$ Although the first statement could be agreed with, albeit with some serious reservations, it would be difficult not to contest the second. As was shown so convincingly by Martyna Mirecka, who analysed political tracts from the periods when the English and the Scots were discussing possible critical changes in the relationship between their countries, the issue was indeed present in the constitutional discourse and in political argument, but not in a way that would and could significantly impact the form of a future Anglo-Scottish union."

But lawyers and political polemicists active on parliamentary committees or discussing the problem of the union in their writings, such as Sir Henry Savile, Thomas Craig or later Blackerby Fairfax, were not the only people who, at some point, had an opportunity, were willing or were required to become interested

\footnotetext{
${ }^{8}$ There exists a serious disproportion, as Scottish materials have only been used to a very limited degree, but hopefully this will change in the future, although this would require a search for additional new sources in Scottish collections, as well as approaching the problem from a different angle. For some interesting inspirations, see: A. McInnes, 'The Hidden Commonwealth: Poland-Lithuania and Scottish Political Discourse in the Seventeenth Century', in: Citizenship and Identity in a Multinational Commonwealth Poland-Lithuania in Context, 1550-1772, eds. K. Friedrich, B. Pendzich (Leyden, Boston, 2009), pp. 233-26o.

${ }^{9}$ R. Frost, 'Hiding from the Dogs: The Problem of Polish-Scottish Political Dialogue, 1550-1707' in: Scotland and Poland. Historical Encounters, 1550-2010, eds. T.M. Devine, D. Hesse (Edinburgh: Birlinn, 2011), pp. 23-32.

${ }^{10}$ A. Gilman Sherman, 'Poland in the Cultural Imaginary of Early Modern England', in: Journal of Early Modern Cultural Studies, Vol. 15, No 1 (2015), pp. 73-75. For the most notorious example, see: E.A. Mierzwa, 'Polskie inicjatywy unifikacji europejskiej', in: Polityka i Speteczeństwo, Vol. 7 (2010), pp. 129-131.

${ }^{11}$ M. Mirecka, "Monarchy as it should be"? British perceptions of Poland-Lithuaniain the long seventeenth century. PhD dissertation (2015)
} 
in how the Polish-Lithuanian state worked..$^{12}$ So, against all odds, was there any chance that there could have been other groups with deeper, more detailed and more accurate knowledge of this issue that would have allowed them to draw clear comparisons and be inspired by the Polish-Lithuanian system? To answer these questions, it is necessary to focus on British representations of the relations between Poland and the Grand Duchy of Lithuania and the contexts in which the Polish-Lithuanian union appeared in various materials that were instrumental in creating an awareness of Poland-Lithuania as a composite state, and therefore for the way it functioned in the public sphere in Britain in the late-16th and in $17^{\text {th }}$ centuries. It also requires focusing not on representations of specific legal agreements, such as Krewo and Lublin, but instead on British representations of the results of the latter political and legal act. Therefore, the aim of this text is to determine how various groups of the British public might have viewed the state which was formally brought into existence in Lublin in July 1569 , and also what, based on the information then available to them, they could possibly have known about its political culture, and how this was reflected in the various British representations of the way in which the Commonwealth functioned. ${ }^{13}$

To be able to explore these issues, there are several important problems that should be remembered. One of these was access to information. It is obvious that various groups and individuals had different opportunities when it came to gaining knowledge of this, or indeed any, foreign country. This was due to their level of literacy and/or education, social standing, geographical location, financial means, as well as their personal and professional networks. Another

${ }^{12}$ For Savile's extremely interesting observations of the Polish-Lithuanian unions, but ignoring completely the 1569 act, see: H. Savile, 'Historical Collections by Sir Henry Savile' in: The Jacobean Union. Six tracts of 1604 , eds. R.B. Galloway, B.P. Levack (Edinburgh, 1985), pp. 189, 218-222. It was carefully analysed in Mirecka, "'Monarchy", pp. 166-168.

${ }^{13}$ For the purposes of this article, I have concentrated on material written and circulating in English, although some social and/or professional groups were able to take advantage of Latin, Italian, German or French texts. The role of foreign-language material in the British system of knowledge and news circulation with regard to Poland-Lithuania is another interesting issue that should be analysed more fully. 
factor was their motivation and the reasons why they may have needed or wanted to learn more about Poland-Lithuania and the way it functioned. These could vary significantly. In many cases, it was a strictly professional interest (for example, for members of the court elites and royal administration, and merchants); in others, it was more personal, for example due to having visited Poland-Lithuania or having some form of relationship with members of the English or Scottish diaspora living there. ${ }^{14}$

Secondly, it should be remembered that even eye-witness accounts given by people who had an opportunity to visit Poland-Lithuania do not necessarily provide us with much material on which to build. Quite often they simply repeat earlier observations known from other writers (who also often repeated one another), thus offering no verification of these statements.

Finally, printing and news underwent a veritable revolution in 16th and 17th-century Europe. Due to important developments on the book market and the emergence of new media, especially the serial and periodical press, the way information was transferred between and within various countries had changed, as had its role in society. This is also of key importance when discussing the perception of Poland-Lithuania in Britain; although some research has already been conducted on English materials, ${ }^{15}$ Scotland, as was mentioned above, still requires more attention.

To develop a convincing argument, it is necessary to analyse several types of sources that best convey how the Polish-Lithuanian union was presented at various levels, mainly political and geographical, in different kinds of material produced by and/or targeted at different groups of Britons.

\footnotetext{
${ }^{14}$ Unfortunately, at this point, private correspondence sent from Poland-Lithuania to England and Scotland has been rather neglected as research material, so we are simply unable to draw any conclusions based on this potentially highly interesting primary source, see: footnote no 8.

${ }^{15}$ A. Kalinowska, "Wee have tidings out of Polonia": English Corantos, News Networks, and the Polish-Lithuanian Commonwealth' in: News in Early Modern Europe Currents and Connections, eds. S. Davies, P. Fletcher (Leyden, Boston, 2014), pp. 41-57; A. Kalinowska, M. Mirecka, 'Bohater czy malkontent? Odbiór Jana Sobieskiego w Wielkiej Brytanii w świetle "London Gazette"', 1665-1674, in: Marszatek i hetman koronny Jan Sobieski, ed. Dariusz Milewski (Warszawa, 2014), p. 295 ff.; G. Sliesoriūnas, 'The Image of Lithuania in English Publications in the 17th Century', in: Lithuanian Historical Studies, Vol. 16 (2011), pp. 106-114.
} 
The first category can be described as material available to or produced by the 'selected few', members of the elites, people with close links to the court or administration, etc. They had the unprecedented advantage of having access to material normally unavailable or barely available to others, such as diplomatic correspondence or other key documents, sometimes with first-hand knowledge of Poland-Lithuania, as well as extensive news networks; they were also usually well read, thus making it easier for them to fully contextualise the information they received. Moreover, they could have been the very people that would have been involved, in a number of ways, in the discussions regarding the future shape of the Anglo-Scottish union, as is illustrated by the presence on the parliamentary commission of 1604 dealing with the projects concerning Anglo-Scottish union, of Sir George Carew and John Herbert, two former Elizabethan ambassadors to Poland-Lithuania. ${ }^{16}$

The materials they produced usually had a limited circulation. They were almost always in manuscript form, and accessible only to a small group of people of similar standing, or even only to the monarch and/or his or her closest circle. ${ }^{17}$ One of the most striking examples of such a text is A Relation of the State of Polonia A.D 1598 by John Peyton the Younger, a young member of the English elite working for Robert Cecil..$^{18}$ This text, described

${ }^{16}$ Carew, Sir George (1556-1612), Oxford Dictionary of National Biography, https:// doi-org/idm.oclc.org/10.1093/ref:odnb/4627, on Herbert: The History of Parliament, http://www.histparl.ac.uk/volume/16o4-1629/member/herbert-sir-john-15331617\#footnote41_eklo1gd. (accessed 202110 11).

${ }^{17}$ This differed from the Venetian Relazioni, which were widely circulated, so some copies were available to the reading public not only in Venice and Italy, but even in England, de Vivo, 'How to read', pp. 33-36.

${ }^{18}$ The manuscript preserved in the British Library was published by Charles Talbot: Elementa ad Fontium Editiones, Vol. 13: Res Polonicae ex Archivo Musei Britannici, I pars, 'Relation of the State of Polonia and the United Provinces of that Crown anno 1598', ed. C.H. Talbot (Romae, 1965). Another copy was discovered in 2013 and acquired by the University of St Andrews (MS 38902). For more on this, see: S. Sobecki, 'A New Manuscript of John Peyton's A Relation of the State of Polonia (1599-1619)', in: The Library, 7th series, Vol. 16, No 1 (2015), pp. 80-87. Previously on the authorship of the text, see: A. Kalinowska, 'William Bruce a autorstwo "A relation of State of Polonia [...] Anno 1598", in: Przeglad Historyczny, Vol. 102, No 2 (2011), pp. 193-204, and S. Sobecki, 'John Peyton's "A Relation of the State of Polonia" and the Accession of King James I, 1598-1603', in: The English Historical Review, Vol. 129, No 540 (2014), pp. 1079-1097. 
as belonging to 'the more sophisticated written achievements in Elizabethan intelligence gathering, ${ }^{19}$ was later delivered to James VI/I and his secretary of state. In his account, Peyton decided to go into detail when describing the post-1569 union, as well as its origins. ${ }^{20}$ Starting with Jagiello, he presented a general outlook of the connections between Poland and Lithuania, but stressed that the Union of Lublin was more the result of political actions by the Poles than voluntary commitment by the two political bodies, especially as the Lithuanians opposed the incorporation of the Podlasie, Volhynian and Kyiv voivodships. They finally did decide to accept the need for the union only because of the prospect of Sigismund Augustus' death without issue. ${ }^{21}$ Peyton listed several reasons for their opposition, including the stable nature of the Lithuanians, who hated the idea of significant changes in the way their country was organised, to the fear of being dominated by the Poles, who would outnumber them in Parliament and during royal elections, and would have much easier access to the king. Even though these issues were resolved, Peyton's final verdict on the union was that 'howsoever they are ioyned by the kings cession, and statute, yet will they hardly growe into one body, the Lithuanians upon the former causes still seeking a severalitie from the kingdom. ${ }^{22}$ This was confirmed later, when he mentioned that Lithuanians emphasised that 'all the [royal] elections [...] have ben passed without the consent of the greate Duchy contrary to the express statutes and convenantes of union.' ${ }^{23}$ What is crucial is that Peyton described in detail the system created by the Lublin agreement, including the common parliament, as well as the institutions and offices that remained separate. ${ }^{24}$

${ }^{19}$ S. Sobecki, “A man of curious enquiry': John Peyton's Grand Tour to central Europe and Robert Cecil's intelligence network, 1596-16o1", in Renaissance Studies, Vol. 29, No 3 (2014), p. 409 .

${ }^{20}$ 'Relation of the State of Polonia', 32. Peyton referred here to Lithuania as 'the second mayne State of the Crowne of Polonia'.

\footnotetext{
${ }^{21}$ Ibid., p. 36 .

${ }^{22}$ Ibid., p. 37 .

${ }^{23}$ Ibid., pp. 134-135.

${ }^{24}$ Ibid., p. 76 .
} 
Peyton's text serves as a good illustration of what the members of the court and administrative elites had a chance to learn, had they so wished, as it required some effort, about the way in which the Commonwealth functioned. At the opposite end of the spectrum, there is Edmund Tilney's representation of Poland-Lithuania in his work Topographical descriptions, regiments, and policies. ${ }^{25}$ Not only was it much shorter and less detailed, which can be justified by the fact that the treaty dealt with a number of countries and was intended as general reference material for members of the English diplomatic corps $;^{26}$ furthermore, it also almost entirely ignored the realities of the union, in fact the union itself. Tilney called Lithuania one of Poland's 'great provinces', together with Prussia, Masovia, Livonia and others, ${ }^{27}$ and accused the Lithuanians and Livonians of practising idolatry, ${ }^{28}$ although he emphasised Lithuanian military and economic potential by specifying the number of soldiers and revenues normally provided by the Grand Duchy. Last but not least, he summed up the common history of Poland and Lithuania by explaining that after Jagiello's marriage to Hedwig, the duke had decided to become a Christian by 'the good $\mathrm{p}[\mathrm{er}]$ svasion of his wife and the others, with a great part of his countrie', and that subsequently Jagiello's descendants ruled for the next 189 years, until the death of Sigismund Augustus, resulting in a 'great controversie' among the possible candidates during the election of $1572 .{ }^{29}$ Even when describing institutions that had been transformed by the Union of Lublin and were embodiments of the dual character of the state, like the Senate or the key state offices, Tilney, unlike Lippomano and Peyton before him, did not find it at all necessary to refer to this fact. ${ }^{\circ}$

${ }^{25}$ The Folger Shakespeare Library, via LUNA: Folger Digital Image Collections, Edmund Tilney, 'Topographical Descriptions, Regiments and Policies', MS V.b.182, pp. $123 \mathrm{v}-24 \mathrm{~V}$.

${ }^{26}$ Diplomatic Intelligence on the Holy Roman Empire and Denmark during the Reigns of Elizabeth I and James VI. Three Treatises, ed. D.S. Gehring (London, 2016), p. 28.

\footnotetext{
${ }^{27}$ Tilney, 'Topographical Descriptions', p. $123 \mathrm{v}$.

${ }^{28}$ Idem ibid., p. 124r.

${ }^{29}$ Idem ibid., p. 124r.

${ }^{30}$ Idem ibid., p. $124 r$.
} 
Another source belonging to this selective category of exclusive materials are the diplomatic reports delivered by the English, and later Stuart diplomats active in Poland-Lithuania. Because, unlike the Venetian diplomats, they were not obliged to produce final reports dealing with wide-ranging topics concerning the country, it is necessary to look instead at their correspondence and journals. ${ }^{31}$ Consequently, we are dealing here with materials which largely present their observations on the functioning of the union from the far more practical perspective of their own duties. There is no doubt that the political system introduced by the Union of Lublin had serious consequences for the work of the diplomats, who had to respond to various challenges resulting from the fact that they were unable to rely on experience gained in other countries with different political and constitutional settings.

Surprisingly, they left relatively few personal observations on how the union impacted the way the system operated. Instead it was more natural for them to simply acknowledge some of its features: for example, they did not elaborate on the necessity or the need to follow the king to Lithuania, or on the presence of Lithuanian senators or envoys during the Sejm, which they tended to describe as a Polish institution. ${ }^{32}$ Only John Herbert found it necessary to explain in his report to Francis Walsingham, the presence of 'members of the great Duchy of Littaw, nowe united and annexed for ever to the Crowne of Poland' during the convocation of senators in Lublin which was held before the Sejm of $1585 \cdot{ }^{33}$ Interestingly, this did not change the fact that the Sejm was recognised very early on as being the key element of the Commonwealth's political system. In 1595, Christopher Parkins emphasised that important decisions 'cannot in this Kingdom

${ }^{31}$ The only attempt to produce a more elaborate final report was performed by Sir George Carew, who delivered a short Latin summary of his mission, which included his detailed observations on Sigismund III and Gdańsk, similar to those typical of Relazioni, Elementa ad Fontium Editiones, Vol. 4: Res Polonicae Elisabetha I Angliae regnante conscriptae ex Archivis Publicis Londoniarum, ed. C.H. Talbot (Romae, 1961), pp. 238-251.

${ }^{32}$ See, for example: Sir Thomas Roe's journal, The National Archives (hereafter TNA), State Papers Poland 88 (hereafter: SP 88), Vol. 7, p. 421.

${ }^{33}$ Elementa ad Fontium Editiones, Vol. 4, p. 68. 
[the Commonwealth] be sufficientilie handled but onely by Parlament, ${ }^{34}$ and all diplomats in the following decades did try to attend the parliamentary sessions regularly. ${ }^{35}$

The Sejm was for the British ambassador and agents also a 'point of contact' with both Polish and Lithuanian officials. Again, it is evident that the Polish-Lithuanian elite was perceived as being very homogeneous. Neither Elizabethan nor Stuart diplomats treated members of the Polish and Lithuanian elites differently, apart from situations when specific circumstances made them depend on the influence of local magnates; for example, during Charles I's conflict with his Scottish subjects, Francis Gordon organised transports of gunpowder from Lithuania for the royal troops with help from Janusz and Bogusław Radziwill..$^{6}$ In general, the diplomats considered the senators and influential magnates helpful and/or useful based on their political influence, position, the office they held, or their connections with England, regardless of which part of the Commonwealth they came from. This can be observed in the journals of both Sir Thomas Roe (1629) and Lawrence Hyde, later Earl of Rochester (1676), and diplomatic correspondence from various periods. ${ }^{37}$ Even in the most striking case of Christopher Radziwill, the voivode of Vilnius, in the early 1630 s de facto the most influential man in Poland-Lithuania, who played a crucial role in Stuart policy regarding the Commonwealth, he was described as being 'in great favour with this king, and a Prince of Great power

${ }^{34}$ Elementa ad Fontium Editiones, Vol. 4, p. 170; Elementa ad Fontium Editiones, Vol. 17: Res Polonicae ex Archivo Musei Britannici, II pars, C.H. Talbot (Romae, 1967), p. 155 .

${ }^{35}$ This was confirmed by their correspondence, itineraries and financial records. The diplomats themselves often insisted on being present during the parliamentary session, see: Francis Gordon's suggestions that he should be allowed to attend the Sejm of 1638 despite being earlier recalled from the Warsaw court, SP 88, Vol. 10, p. $5^{8}$. Also, for example: Elementa ad Fontium Editiones, Vol. 4, pp. 158, 161.

${ }^{36}$ SP 88, Vol. 10, pp. 113v, 194, 200.

${ }^{37}$ Roe's journal, SP 88, Vol. 7, pp. 409-440, Hyde's journal, The Correspondence of Henry Hyde, Earl of Clarendon and of His Brother Laurence Hyde, Earl of Rochester: With the Diary of Lord Clarendon from 1687 to 1690, Containing Minute Particulars of the Events Attending the Revolution: and the Diary of Lord Rochester During His Embassy to Poland in 1676, Vol. 1 (London, 1828), pp. 589-624. 
in this kingdome. He is the Prime protector and Mantainer of true religion in all Poland and hathe done much for the libertie of the Reformed Churches in this Parlament' ${ }^{3}$

Finally, when discussing more 'exclusive' materials that would have circulated in a rather limited way, but which are now an important indication of how Poland-Lithuania was being presented in Britain among or to the court and local elites, it is necessary to draw attention to professional news writers and academics. ${ }^{39}$ One of the elements of the information revolution that occurred in Britain in the early 17 th century was the emergence of a group of professional or semi-professional novellantes, who compiled and transmitted the latest news, both domestic and foreign, by sending it on a regular basis to their friends, and in some cases to clients who paid for their services. ${ }^{40}$ Their newsletters very often contained the same information that was published in more widely accessible printed materials such as corantos, but they usually also made use of additional and unique sources, and could therefore provide a more detailed commentary on the news they delivered. One such person was the Reverend Joseph Mead, who for nearly ten years provided the latest news available in London to his friend and patron Sir Martin Stuteville, a member of the local elite in Suffolk. ${ }^{41}$ In his letters, although he also reported on events that were taking place in or which were directly connected to Poland-Lithuania, he did not, as some people have already discussed here, acknowledge the existence of the union. During the period covered by his newsletters, there were two moments

${ }^{38}$ SP 88, Vol. 8, p. 122. Radziwill's special role during the election of 1632 was also emphasised in several accounts of this event delivered to the secretary of state, cf. SP 88, Vol. 8, pp. 118-21v, British Library (hereafter BL), MSS Stowe 743, pp. 88-88v.

${ }^{39}$ The two examples presented below serve only as an illustration. There are a number of other cases that, when carefully analysed, can provide us with a deeper understanding of the way Polish-Lithuanian links were perceived among the intellectual elites, e.g. the correspondence of Samuel Hartlieb, or of Comenius, who followed events in Poland-Lithuania on a regular basis.

${ }^{40}$ More on newsletters as a part of the news market: I. Atherton, 'The Itch Grown a Disease: Manuscript Transmission of News in the Seventeenth Century', in: The Prose Studies. History, Theory, Criticism, Vol. 21, No 2 (1998), pp. 39-52.

${ }^{41}$ D. Randall, 'Joseph Mead, Novellante: News, Sociability, and Credibility in Early Stuart England', in: Journal of British Studies, Vol. 45, No 2 (2006), p. 297. 
when such events featured regularly in his reports: the Commonwealth's conflict with the Ottoman Empire in 1621, and the war with Sweden between 1626 and 1629. However, even when the news reports on the Swedish war dealt predominantly with the military situation in Livonia, he never once mentioned the Grand Duchy, or the fact that the Lithuanian forces had the main role there. Similarly, he did report the convening of the Sejm of $1627,{ }^{42}$ but was totally silent about the Swedish-Lithuanian truce at Baldemojza earlier that year.

Yet another, different example of a text, that was, at least for some time, available only to a very narrow group of potential readers, almost certainly of the same profession, namely academics, was the Reverend Robert South's account of his visit to PolandLithuania as a member of the British embassy sent by Charles II to John III Sobieski. ${ }^{43}$ His work is a combination of information gained from other authors (from Kromer to Gaspard de Tende) and his own observations, covering a variety of topics: from the current king and his wife, whom South met while accompanying Ambassador Rochester to Żółkiew, where the court resided at the time ${ }^{44}$ to the history of the country, its parliamentary system and everyday customs. Lithuania was present in this narrative, albeit in a surprisingly limited way. South included a detailed account of Vilnius, which he described as 'the capital of Great Dutchy of Lithuania, ${ }^{45}$ and informed his readers that Lithuania had its own Tribunal, and that its legal system differed from the one observed in

${ }^{42}$ BL, MSS Harley 39o, p. 243; see also MSS Harley 389, p. 487v.

${ }^{43}$ Printed in 1717 , it was originally written for the author's friend Edward Pococke, Regius Professor of Hebrew in Oxford, and might have circulated in academic circles. R. South, Posthumous works of the late Reverend Robert South, D.D. Containing, sermons on several subjects, viz. I. On the martyrdom of King Charles I. II. Ecclesiastical Constitutions to be strictly Maintain'd. III. The Certainty of a Judgment after this Life. IV. An Account of his Travels into Poland, with the Earl of Rochester, in the Year 1674. V. Memoirs of his Life and Writings. VI. A true copy of his last will and testament (London, 1717), pp. 22-106.

${ }^{44}$ Ibid., pp. 24-27. There is an uncanny resemblance between South's observations of John III and his queen, Maria Casimira, and the way they were presented by Bernard Connor, which may suggest that Connor had an opportunity to use South's manuscript in the late 169 os.

${ }^{45}$ Ibid., p. 31. 
other parts of the state. ${ }^{46} \mathrm{He}$ also elaborated on the parliamentary rule that the speaker of every third Sejm should come from the Grand Duchy (alternata), ${ }^{47}$ but he clearly found it unnecessary to explain in any way whatsoever the relationship between Poland and Lithuania. Furthermore, he generally referred to all citizens of the Commonwealth as 'the Poles'.

Was this mostly Poland-oriented approach to the realities of the union found in the texts available largely to selected readers also present to the same extent in the materials addressed to the general reading public both in England and Scotland? ${ }^{48}$ The answer is definitely affirmative, even in the case of texts that could be expected to have stressed the composite structure of the Commonwealth. A propaganda book published in London in 1641 by Eleazar Gilbert, a Scottish preacher from Kèdainiai working for the Radziwills, was not only entitled The News from Poland, but it also described Vilnius as being 'situated in the heart or centre of seven or eight ancient Kingdomes, now annexed and allied to the Crown of Poland, namely Lithuania, Samogitia, Courlandia, Livonia, Alba-Russia, Prussia and Masovia'. ${ }^{49}$ When, however, referring to Vladislaus VI's letter restricting Protestants' freedom of religious practice in Vilnius, Gilbert stated that it was issued in Warsaw, when the Parliament was in session, but 'given under the Seal of the Great Dukedom of Lithuania', which may have been quite confusing for readers unfamiliar with the specifics of the system. ${ }^{5^{\circ}}$

${ }^{46}$ Ibid., pp. 71-72, 76 .

${ }^{47}$ Ibid., p. 82.

${ }^{48}$ For the purposes of this text, the author has used the Scottish Books 15051700 (Aldis updated) catalogue and ESTC to locate the publications dealing with Poland-Lithuania printed in Scotland, but this data still needs to be analysed in the context of the book and press markets both in England and Scotland. More research is required here, especially in the light of what is known about print culture in Scotland, R.S. Spurlock, 'Cromwell's Edinburgh press and the development of print culture in Scotland', Scottish Historical Review, Vol. 9o, No 230 (2011), pp. 179-203.

${ }^{49} \mathrm{E}$. Gilbert, Nevves from Poland. Wherein is declared the cruell practice of the popish clergie against the Protestants, and in particular against the ministers of the city of Vilna, in the great dukedome of Lithuania, under the governement of the most illustrious prince, Duke Radzivill. Faithfully set downe by Eleazar Gilbert; minister to the foresaid prince, and preacher to the Scots congregation in Keydon. Read it over, and you shall find it a most unparalelld story for barbarous treacherie (London, 1641), p. 7 .

${ }^{50}$ Gilbert, Nevves from Poland, p. 17. 
Poland-Lithuania was presented in a similar manner in geographical compendia written and published in English. Neither George Abbot nor Peter Heylyn, the two most popular authors of these kinds of texts written in English in the late-16th and early-17th centuries, made any reference at all to the union in early editions of their books..$^{1}$ This, however, changed with time, but when Heylyn finally included more detailed information on Poland-Lithuania, he simply explained that 'Poland is an Aggregate Body, consisting of many distinct Provinces, United into one Estate, of which Poland, being the predominant, hath given the name of the rest, called all together the Realm of Poland. $5^{52}$

Other authors took a similar approach. In his book on European universities published in 16oo, Samuel Lewkenor described Vilnius (which he had happened to visit). In it, he explained that upon his marriage to Hedwig, daughter 'to the king of Polonia', Jagiello simply 'annexed unto this kingdom the Dukedom of Lithuania. ${ }^{53}$ In the 1680s, Robert Morden quoted Heylyn, but tried to be more precise by explaining that Lithuania was 'the greatest Province of all of those which compose the Estates of the Crown of Poland'.54 He admitted, however, that the Grand Duchy had its own ranks of officials, identical to those in Poland. ${ }^{55} \mathrm{He}$ also described the

${ }^{51} \mathrm{Cf}$. G. Abbot, A briefe description of the whole world (London, 1599), B2-B2v and P. Heylyn, Mikrókosmos A little description of the great world (Oxford, 1631), p. $35^{2}$.

${ }^{52} \mathrm{P}$. Heylyn, Cosmographie in four bookes. Containing the chorographie and historie of the whole vvorld, and all the principall kingdomes, provinces, seas, and isles, thereof. By Peter Heylyn (London, 1652), p. 165.

${ }^{53} \mathrm{~L}$. Lewkenor, $A$ discourse not altogether vnprofitable, nor vnpleasant for such as are desirous to know the situation and customes of forraine cities without trauelling to see them Containing a discourse of all those citties wherein doe flourish at this day priuiledged vniuersities. Written by Samuel Levvkenor Gentleman (London, 16oo), p. 55.

${ }^{54} \mathrm{R}$. Morden, Geography rectified: or, A description of the vvorld, in all its kingdoms, provinces, countries, islands, cities, towns, seas, rivers, bayes, capes, ports; their antient and present names, inhabitants, situations, histories, customs, governments, \&c. As also their commodities, coins, weights, and measures, compared with those at London. Illustrated with above sixty new maps. The whole work performed according to the more accurate discoveries of modern authors (London, 1680), p. 116.

${ }^{55}$ Morden, Geography rectified, 117. Interestingly, in the 1693 edition, Morden added a short historical overview that mentioned Jagiello and his marriage to Hedwig, but ignored the union completely. R. Morden, Geography rectified: or, A description of the World, in all its kingdoms, provinces (London, 1693), p. 82. 
country's political system as dominated by the Senators, 'so when we name the Quality of the State, we may call it the Kingdom and Common-wealth of Poland. ${ }^{56}$ In turn, Moses Pitt made mention of the act of 1569 , and even recalled some articles of the union (such as articles 5 and 8), but in a rather confusing way. His readers could learn that the Poles had an equal voice to the Lithuanians in electing the Grand Duke, and that the election itself should be announced by the Archbishop of Gniezno; he was, however, correct in saying that the parliaments should be held by turn in Poland and Lithuania. ${ }^{57}$ Finally, the description in Edmund Bohun's Dictionary simply indicated that in 1569 'the Dukedom was for ever united to the Kingdom of Poland. $5^{8}$ An interesting exception is a publication by Robert Stafford, who on describing Poland in the first decade of the 17th century, did not mention Lithuania among the Polish provinces, but listed it as a separate 'kingdom', 'governed by a Duke, but subject unto this king of Poland'.59

The situation did not differ greatly in the case of two typical travel accounts penned by authors who had visited Poland-Lithuania, which were actually printed in the 17 th century. Fines Moryson in his An Itinerary (1617) and William Lithgow in his Nineteen Years Travels (London, 1682) did not even mention Lithuania, although this can be explained by the fact that neither of them managed to visit the Grand Duchy. Lithgow, however, did provide his readers with a short description of the country and its main features, in which it would have been quite natural to recall the union. ${ }^{60}$

${ }^{56}$ Morden, Geography rectified, pp. $113^{-114}$.

${ }^{57}$ M. Pitt, The English Atlas (Oxford, 1680), Poland 20. These new regulations on the parliamentary procedure were quite recent, as they were introduced in 1673 . Pitt's article on Poland seems to be the first such extensive and detailed account of the political system of the Union, cf. Mirecka, “Monarchy", p. 176.

${ }^{58} \mathrm{E}$. Bohun, A geographical dictionary representing the present and antient names and states of all the countries, kingdoms, provinces, remarkable cities, universities, ports, towns, mountains, seas, streights, fountains, and rivers of the whole world ... (London, 1695), p. 234. Moreover, he described Lithuania as 'a Province and Grand Dukedom belonging to the Kingdome of Poland'.

${ }^{59}$ R. Stafford, A geographicall and anthologicall description of all the empires and kingdomes, both of continent and ilands in this terrestriall globe. Relating their scituations, manners, customes, prouinces, and gouernements (London, 1618), p. 26.

${ }^{60}$ F. Moryson, An itinerary vvritten by Fynes Moryson Gent. First in the Latine tongue, and then translated by him into English: containing his ten yeeres trauell 
As can be seen from this overview of various texts, English readers were able to acknowledge the existence of the PolishLithuanian state both in the late 16th and for the best part of the $17^{\text {th }}$ century, and occasionally they could learn more about the general mechanisms behind the way it functioned in the post1569 period, but their knowledge must have been rather patchy, because the information they were given was quite inaccurate. The publication that finally brought more clarity was Bernard Connor's History of Poland, published in $1698 .{ }^{61}$ This was primarily a compilation, albeit a critical one, of earlier texts, from Kromer to contemporary French writers, but it included a whole chapter on the Grand Duchy, which was not just another description of one of multiple 'Polish provinces', but confirmed Lithuania's equal status within the Commonwealth: 'The Great Duchy of Lithuania [...] tho subject to the King of Poland, as Scotland to the King of England, yet is a distinct nation from this Kingdom, having different Customs, a different Dialect, and particular Privileges, tho one Diet served them both. ${ }^{62}$

While describing the origins of the Union, Connor returned, of course, to Krewo, but stated that earlier arrangements were confirmed in Lublin where it was agreed, that Lithuania should enjoy its own particular Laws and Privileges, and be constituted as a part of the Polish Common-wealth; insomuch that nothing of importance was for the future to be transacted therein, without the voluntary Concurrence of these states. ${ }^{63}$

Connor also referred to situations when these rules were to be put into practice, for example during the royal elections. When writing about the election of Wiśniowiecki and Sobieski, he

through the tvvelue dominions of Germany, Bohmerland, Sweitzerland, Netherland, Denmarke, Poland, Jtaly, Turky, France, England, Scotland, and Ireland (London, 1617); W. Lithgow, The totall discourse, of the rare aduentures, and painefull peregrinations of long nineteene yeares trauayles from Scotland, to the most famous kingdomes in Europe, Asia, and Affrica... (London, 1632).

${ }^{61} \mathrm{~B}$. Connor, The history of Poland; in several letters to persons of quality... Vols. 1-2, (London, 1698). Connor spent relatively little time in Poland, only about ten months in 1694, but it seems he might have used this time for acquiring some material that he used later while writing his book.

${ }^{62}$ Ibid., Vol. 1, p. 302.

${ }^{63}$ Ibid., Vol. 1, p. $3 \circ 3$. 
elaborated on the tensions between the Poles and the Lithuanians who supported different candidates. When dealing with August II's election to the throne, Connor was much more direct by informing his readers that 'for their Constitution no election can be really Lawful, nor any Law can be legally made without the universal Consent of the Lords and Commons of the both states, Poland and Lithuania, assembled in Parliament. ${ }^{36}$

It is therefore clear that readers of geographical tracts and travel accounts were provided with substantial information on Poland-Lithuania, although it was far from precise and insufficiently detailed to enable them to put together a comprehensive picture of the post-1569 Polish-Lithuanian political system. Were the newly emerging news media able to add or clarify, by reporting the latest events, information on this? Or maybe the news pamphlets, corantos, newsbooks and late-17th century periodicals only added to this confusing image of the Polish-Lithuanian union?

The earliest news pamphlet that could possibly have informed readers on the subject of the union, $A$ True reporte of the taking of the great towne and castell of Polotzko by the King of Polonia, published in 1579, did not explain the situation. ${ }^{65}$ Instead, it presented Stephen Bathory's war with Muscovy as a pre-emptive action aimed at protecting 'the great Dukedome of Litto, and principallye of the Towne of Villo' against another Muscovite invasion, but also trying to 'recouer that same Towne [Połock] to the Crowne of Poland againe, as it hath beene in times past', ${ }^{66}$ even though it had, in fact, belonged to the Grand Duchy.

The same can be said about English corantos dating from the 1620 s and 163 os, not only when referring to the way they informed readers about the specifics of Polish-Lithuanian political realities when presenting the latest events, but also to the presence of Lithuanian news in general. ${ }^{67}$ When in 1623 one of the

${ }^{64}$ Ibid., Vol. 1, p. 208.

${ }^{6} \mathrm{~A}$ True reporte of the taking of the great towne and castell of Polotzko by the King of Polonia (London, 1579).

${ }^{66}$ Ibid., A2v.

${ }^{67}$ For news from Poland-Lithuania in corantos, see: A. Kalinowska, "Wee have tidings out of Polonia", pp. 41-57. For corantos in general, see: J. Raymond, 'News', 
reports published in London discussed the progress of the war with Gustavus Adolphus, it was indicated that 'the States of his [Sigismund III] Subjects of Lituania' opted for a truce, and were generally against any military actions against Sweden, provided the peace treaty secured their interest. ${ }^{68}$ In May 1625 the picture was, however, very different, as in a news item datelined from Warsaw and describing a session of the Sejm, it was mentioned that only Lithuanian envoys agreed to the new subsidy, but on the condition that it would be spent on the defence against Sweden. ${ }^{69}$ There were also other reports indicating, for example, the end of hostilities between Sigismund III and Christopher Radziwill shortly before the king's death; ${ }^{70}$ otherwise, references to Lithuania were practically non-existent. The only time it was mentioned in the news item's dateline occurred in 1622 , when a report from 'Riga in Lithuania' ${ }^{71}$ gave information about the start of talks between Swedish and Polish ambassadors.

This can be explained to some extent by the news networks used by the editors of the London coranto who relied on a limited number of sources which came directly from Poland-Lithuania; of the nearly 200 news items coming from or dealing with the Commonwealth published by corantos between 1620 and 1641 , only 28 were datelined from this country, with nearly half being described as coming from Gdańsk, and only two from Warsaw. The majority of reports covering the situation and events in Poland-Lithuania printed in the corantos originated from the Empire. ${ }^{7^{2}}$

The emergence of the periodical press, such as newsbooks in the 1640s, the London Gazette in the mid-166os, and other periodical publications in the final decades of the $17^{\text {th }}$ century, brought

in: The Oxford History of the Popular Print Culture. Cheap Print in Britain and Ireland to 166o, Vol. I, ed. J. Raymond (Oxford, 2011), pp. 380-383; J.E.E. Boys, London's News Press and the Thirty Years War (Woodbridge, 2011), pp. 17-179; M. Frearson, 'London Corantos in the 1620s', in: Studies in Newspaper and Periodical History, Vol. 1, Nos 1-2 (1993), pp. 3-17.

${ }^{68}$ The newes of this present weeke..., No 31 (12 May 1623), pp. 8-9.

${ }^{69}$ The continuation of our weekly newes, No 20 (5 May 1625), p. 14.

${ }^{70}$ The continuation of our forraine avisoes, No 26 (6 June 1632), pp. 2-3.

${ }^{71}$ Count Mansfields proceedings since last bataille (s.n.) (9 September 1622), p. 11.

${ }^{72}$ Kalinowska, “"Wee have tidings out of Polonia"', p. 51. 
important changes, although only with time. This was partly due to the fact that the editors at that time had at their disposal much wider news networks, or, as in the case of Marchmont Needham and later Joseph Williamson, had access to government sources, which were otherwise unavailable to the wider public, and also partly because of the changes in editorial practices. ${ }^{73}$ This is reflected clearly in the way newsbooks in 1655 presented to British readers the key moment in the relations between the Crown and the Grand Duchy, i.e. the Treaty of Kiejdany and its October confirmation. When news of the events reached London, readers were already aware of the Swedish invasion and the tragic situation in the Grand Duchy, which was struggling, since it was also at war with Russia. ${ }^{74}$ The publication of An Act of the Nobility and Estates of the great Dukedom of Lithuania, the goal of which was purportedly the preservation of the Commonwealth by recognising Charles X Gustavus as lawful grand duke, ${ }^{75}$ could therefore have easily been written into the already-existing narrative.

For the remainder of the decade, and in the 166os, developments in Poland-Lithuania, including reports on the conflict with Russia, still appeared in English periodicals (as well as in one of the Scottish publications of this type, Mercurius Caledonius ${ }^{76}$ ), and

${ }^{73}$ Raymond, 'News', pp. 384-97.

${ }^{74}$ London newsbooks provided extensive coverage of the Swedish invasion in the summer of 1655, cf. for example: Mercurius Politicus, No 270 (9-16 August 1655), pp. 5537, 5541; Faithfull scout, No 240 (10-17 August 1655), p. 1918; Moderate Publisher [s.n.] (24-31 August 1655), p. 6o; Perfect account of the daily intelligence, No 246 (19-26 September 1655), p. 1968; Perfect proceedings of state-affaires, No 313 (20-7 September 1655), p. 4958. For reports specifically on the situation in Lithuania, see, for example: Mercurius Politicus, No 275 (13-20 September 1655), p. 5625; Mercurius Politicus, No 276 (20-7 September 1655), p. 5635. In October 1655, the number of available newspapers was limited due to Cromwell's new regulations, so news on further developments in Poland-Lithuania were from then on provided only by Mercurius Politicus and Public Intelligencer.

${ }^{75}$ Mercurius Politicus, No 282 (1-8 November 1655), p. 5738, No 284 (15-22 November 1655), p. 5758 ff.; A. Kotljarchuk, In the Shadows of Poland and Russia. The Grand Duchy of Lithuania and Sweden in the European Crisis of the mid-17th Century (Huddinge, 2006), pp. 141-142.

${ }^{76}$ This short-lived publication, although focusing mainly on domestic issues, did provide its readers with foreign news, including some reports on events in Poland-Lithuania. For example, correspondence datelined from Gdańsk mentioning the forthcoming Sejm (Estates of Poland), Mercurius Caledonius, No 3 (15-22 February 1661), 
it can be assumed that this contributed to the stronger recognition of Lithuania as one of the two key parts of the Commonwealth, and playing an important role in its political system.

This was confirmed later, for example, by the reports on subsequent royal elections, emphasising the different preferences of the Poles and the Lithuanians. The most important news publication, The London Gazette, covered extensively the events in Warsaw during the election of 1674 . As a result, in early June, its readers could learn about the conflict between the Poles and Lithuanians over whether 'the Piast' candidacy (described as 'a Native either of Poland or Lithuania') should be taken into consideration. ${ }^{77}$ Two weeks later, another news item confirmed that some of the Lithuanian electors had left Warsaw. They claimed it was in protest against procedural issues, but the report suggested that in fact they did so because some of their postulates were not included in the Pacta Conventa. This, however, did not stop the rest of the Parliament (i.e. mainly Poles) from concluding the election and setting the date for the coronation. ${ }^{7}$

In the 169os, it was reinforced even further by the fact that a number of detailed reports covering events in Lithuania's political life, although they were still often described more generally as taking place 'in Poland', appeared in The present state of Europe, or, the historical and political mercury, a monthly periodical based on a similar publication published in The Hague, devoted entirely to foreign news. ${ }^{79}$

To conclude, there is strong evidence that awareness of the existence of the Polish-Lithuanian union in Britain in the late 16th and $17^{\text {th }}$ centuries was not limited to a narrow group of lawyers and polemicists directly involved in discussions on the relations between England and Scotland. Against all the odds, including notoriously downplaying or simply denying the fact that after 1569

p. 8. For more on this title, see: J.M. Buckroyd, 'Mercurius Caledonius and Its Immediate Successors, 1661', in: The Scottish Historical Review, Vol. 75, No 157 (1975), pp. 11-21. In the 1650 s, Mercurius Politicus was reprinted in Edinburgh, so at least some Scottish readers had an opportunity to follow the narrative regarding Poland-Lithuania.

${ }^{77}$ The London Gazette, No 890 (1 June 1674), p. 1.

${ }^{78}$ Ibid., No 894 (15 June 1674), p. 1.

${ }^{79}$ Its contents were carefully analysed by Dr Gintautas Sliesoriūnas in his article. 
Lithuania was one of the two parts of the Commonwealth, both of which were equal in status, with its own political identity, and not just a mere Polish province, the legal and practical consequences of the Union of Lublin were present in the narrative offered to various groups of the British public.

However, the image of how the Polish-Lithuanian state operated was rather blurred: the vast majority of authors and editors did not consider it necessary to provide their readers with precise explanations of the basic 'rules of engagement' of the union, or with any reflections on the way it functioned on an organisational level. This, obviously, differed, depending on the kind of materials we are dealing with; for example, short news items in early newspapers were not aimed at presenting the wider context, but rather at transmitting the most current news. Nonetheless, the fact that reports by British diplomats paid so little attention to the Commonwealth's political structure and the way it translated into its political life is quite astonishing. Similarly, what the British knew or could learn about the functioning of the union also evolved with time, since more sources or information were becoming available, and the information itself became more detailed and often more accurate than before. Yet in general, the way the shared Commonwealth was being represented in Britain in the late-16th and $17^{\text {th }}$ centuries cannot be described in any other way than 'far from doing justice' to its creators, institutions and citizens.

\section{Author Details}

Anna Kalinowska is an assistant professor in the Tadeusz Manteuffel Institute of History, Polish Academy of Sciences. Her research interests focus mainly on diplomacy and news networks in Early Modern Europe, and she has published extensively on both subjects. She is currently head of publication and digital resources at the Polish History Museum. She has been a Fulbright Scholar, and a recipient of grants from the British Academy, the National Science Centre Poland, and the Royal Society of Edinburgh.

Address: Tadeusz Manteuffel Institute of History, Polish Academy of Sciences ORCID: 000o-0oo2-3025-4701

Email: akalinowska@ihpan.edu.pl 


\section{Bibliography}

Archival sources:

British Library:

MS Harley, 389, 390,

MS Stowe 743,

The National Archives, Kew:

SP 88 Vol. 1-10

The Folger Shakespeare Library (LUNA: Folger Digital Image Collections):

MS V.b.182

Printed materials:

Primary sources:

Corantos and newsbooks are identified by their short title and number in relevant printed catalogues: F. Dahl, A Bibliography of English Corantos and Periodical Newsbooks 1620-1642 (London: Bibliographical Society, 1952), or C. Nelson and M. Seccombe, British Newspapers and Periodicals 1641-1700 (New York: The Modern Language Association of America, 1987).

ABBOT, George. A briefe description of the whole world (London: John Browne, 1599).

BOHUN, Edmund. A geographical dictionary representing the present and antient names and states of all the countries, kingdoms, provinces, remarkable cities, universities, ports, towns, mountains, seas, streights, fountains, and rivers of the whole world... With a short historical account of the same, and a general index of the antient and Latin names. Very necessary for the understanding of all antient and modern histories, and especially the diverse accounts of the present transactions of Europe. Begun by Edmund Bohun, Esquire. Since continued, corrected and enlarged with great additions thoughout. ... Together with all the corporations and market-towns in England and Wales. The fourth edition. To which are added the general prcecognita of geography, and the doctrine of the sphere. ... With an alphabetical table of the most noted rivers and mountains in England and Wales; ... by John Augustine Bernard (London: Charles Brome, 1695).

CONNOR, Bernard. The history of Poland; in several letters to persons of quality. Giving an account of the present state of that kingdom, historical, political, physical and ecclesiastical; viz. The form of government; the King's power, court and revenues; the senate, senators, and other officers; the religion, Diet, and little Diets, with other assemblies and courts of justice; the inter-regnum; election and coronation of a king and queen, ... the present 
condition of the gentry and commonalty; ... the genius character, languages, customs, manners, military affairs, trade and riches of the Poles. Together with an account of the city of Dantzic: ... a table for each volume; and a sculpture of the Diet in session: with some memoirs from Baron Blomberg. Vol. II. By Bernard Connor, M.D. Fellow of the Royal Society, and member of the College of Physicians; who, in his travels in that country, collected these memoirs from the best authors, and his own observations (London: D. Brown \& A. Roper, 1698).

The Correspondence of Henry Hyde, Earl of Clarendon and of His Brother Laurence Hyde, Earl of Rochester: With the Diary of Lord Clarendon from 1687 to 169o, Containing Minute Particulars of the Events Attending the Revolution: and the Diary of Lord Rochester During His Embassy to Poland in 1676, Vol. 1 (London: Henry Colburn, 1828), pp. 589-624.

Count Mansfields proceedings since last bataille... (Dahl 74).

The continuation of our forraine avisoes... (Dahl 274).

The continuation of our weekly newes... (Dahl 171).

Diplomatic Intelligence on the Holy Roman Empire and Denmark during the Reigns of Elizabeth I and James VI. Three Treatises, ed. D.S. Gehring (London: Camden Society, 2016).

Elementa ad Fontium Editiones, Vol. 4: Res Polonicae Elisabetha I Angliae regnante conscriptae ex Archivis Publicis Londoniarum, ed. C.H. Talbot (Romae: Polish Historical Institute in Rome, 1961).

Elementa ad Fontium Editiones, Vol. 13: Res Polonicae ex Archivo Musei Britannici, I pars, 'Relation of the State of Polonia and the United Provinces of that Crown Anno 1598', ed. C.H. Talbot (Romae: Polish Historical Institute in Rome, 1965).

Elementa ad Fontium Editiones, Vol. 17: Res Polonicae ex Archivo Musei Britannici, II pars, C.H. Talbot (Romae: Polish Historical Institute in Rome, 1967).

Faithfull scout (N\&S 150).

GILBERT, Eleazar. Nevves from Poland. Wherein is declared the cruell practice of the popish clergie against the Protestants, and in particular against the ministers of the city of Vilna, in the great dukedome of Lithuania, under the governement of the most illustrious prince, Duke Radzivill. Faithfully set downe by Eleazar Gilbert; minister to the foresaid prince, and preacher to the Scots congregation in Keydon. Read it over, and you shall find it a most unparalelld story for barbarous treacherie (London: Nathanael Butter, 1641).

HEYLYN, Peter. Cosmographie in four bookes. Containing the chorographie and historie of the whole vvorld, and all the principall kingdomes, provinces, seas, and isles, thereof. By Peter Heylyn (London: Henry Saile, 1652). 
HEYLYN, Peter. Mikrókosmos A little description of the great world (Oxford: William Turner, 1631).

LEWKENOR, Samuel. A discourse not altogether vnprofitable, nor vnpleasant for such as are desirous to know the situation and customes of forraine cities without trauelling to see them Containing a discourse of all those citties wherein doe flourish at this day priuiledged vniuersities. Written by Samuel Levvkenor Gentleman (London: Humphrey Hooper, 16oo).

LIPPOMANO, Girolamo. 'Relazione di Polonia di Girolamo Lippomano 1575', in: Relazioni degli ambasciatori Veneti al senato, Vol. 14, ed. E. Albèri (Cambridge: Cambridge University Press, 2012).

LITHGOW, William. The totall discourse, of the rare aduentures, and painefull peregrinations of long nineteene yeares trauayles from Scotland, to the most famous kingdomes in Europe, Asia, and Affrica. Perfited by three deare bought voyages, in surueighing of forty eight kingdomes ancient and moderne; twenty one rei-publickes, ten absolute principalities, with two hundred ilands. The particular names whereof, are described in each argument of the ten diuisions of this history: and it also diuided in three bookes; two whereof, neuer heretofore published. Wherein is contayned, an exact relation, of the lawes, religion, policies, and gouernment of all their princes, potentates, and people. Together with the grieuous tortures he suffered, by the inquisition of Malaga in Spaine, his miraculous discouery and deliuery thence: and of his last and late returne from the northerne iles (London: Nicholas Okes, 1632).

The London Gazette (N\&S 471).

Mercurius Caledonius (N\&S 290).

Mercurius Politicus (N\&S 361 ).

Moderate Publisher (N\&S 427).

MORDEN, Robert. Geography rectified: or, A description of the vvorld, in all its kingdoms, provinces, countries, islands, cities, towns, seas, rivers, bayes, capes, ports; their antient and present names, inhabitants, situations, histories, customs, governments, \&c. As also their commodities, coins, weights, and measures, compared with those at London. Illustrated with above sixty new maps. The whole work performed according to the more accurate discoveries of modern authors (London: R. Morden and T. Cockeril, 1680).

MORYSON, Fynes. An itinerary vvritten by Fynes Moryson Gent. First in the Latine tongue, and then translated by him into English: containing his ten yeeres trauell through the tvvelue dominions of Germany, Bohmerland, Sweitzerland, Netherland, Denmarke, Poland, Jtaly, Turky, France, England, Scotland, and Ireland (London: John Beale, 1617). 
The newes of this present weeke... (Dahl 111).

Perfect account of the daily intelligence (N\&S 496).

Perfect proceedings of state-affaires (N\&S 599).

PITT, Moses. The English atlas. Volume I. Containing a description of the places next the North-Pole; as also of Muscovy, Poland, Sweden, Denmark, and their several dependances. With a general introduction to geography, and a large index, containing the longitudes and latitudes of all the particular places, thereby directing the reader to find them readily in the several maps (Oxford: Moses Pitt, 1680).

Posthumous works of the late Reverend Robert South, D.D. Containing, sermons on several subjects, viz. I. On the martyrdom of King Charles I. II. Ecclesiastical Constitutions to be strictly Maintain'd. III. The Certainty of a Judgment after this Life. IV. An Account of his Travels into Poland, with the Earl of Rochester, in the Year 1674. V. Memoirs of his Life and Writings. VI. A true copy of his last will and testament (London: E. Curll, 1717).

SAVILE, Sir Henry, 'Historical collections by Sir Henry Savile' in: The Jacobean Union. Six tracts of 1604 , eds. R.B. Galloway, B.P. Levack (Edinburgh: Clark Constable, 1985), pp. 184-239.

STAFFORD, Robert. A geographicall and anthologicall description of all the empires and kingdomes, both of continent and ilands in this terrestriall globe. Relating their scituations, manners, customes, prouinces, and gouernements (London: John Parker, 1618).

A True reporte of the taking of the great towne and castell of Polotzko by the King of Polonia with the manner of the assaults, batteries, undermininges, skirmishes and fyreworkes, that were there vsed from the 11 of August to the 30 of the same month 1579 (London: s.n., 1579).

\section{Secondary sources:}

ATHERTON, Ian. The Itch Grown a Disease: Manuscript Transmission of News in the Seventeenth Century in: The Prose Studies. History, Theory, Criticism, Vol. 21, No 2 (1998), pp. 39-65.

BOYS, Jayne E.E. London's News Press and the Thirty Years War (Woodbridge: Boydell Press, 2011).

BUCKROYD, Julia M. 'Mercurius Caledonius and Its Immediate Successors, 1661', in: The Scottish Historical Review, Vol. 75, No 157 (1975), pp. 11-21.

FREARSON, Michael. 'London Corantos in the 1620s', in: Studies in Newspaper and Periodical History Vol. 1, Nos 1-2 (1993), pp. 3-17.

FROST, Robert. 'Hiding from the Dogs: The Problem of PolishScottish Political Dialogue, 1550-1707' in: Scotland and Poland. Historical Encounters, 1550-2010, eds. T.M. Devine, D. Hesse (Edinburgh: Birlinn, 2011), pp. 21-37. 
GILMAN SHERMAN, Anita. 'Poland in the Cultural Imaginary of Early Modern England', in: Journal of the Early Modern Cultural Studies, Vol. 15, No 1 (2015), pp. 55-89.

KALINOWSKA, Anna. "Kingdome differing from other in Europe..." Rzeczpospolita Obojga Narodów w siedemnastowiecznych tekstach anglojęzycznych", in: Studia Historyczne, Vol. 6o, No 4 (240) (2017), pp. 25-45.

KALINOWSKA, Anna. "Wee have tidings out of Polonia": English Corantos, News Networks, and the Polish-Lithuanian Commonwealth' in: News in Early Modern Europe - Currents and Connections, eds. S. Davies, P. Fletcher (Leyden, Boston: Brill, 2014), pp. 41-57.

KALINOWSKA, Anna, MIRECKA, Martyna. 'Bohater czy malkontent? Odbiór Jana Sobieskiego w Wielkiej Brytanii w świetle "London Gazette", 1665-1674, in: Marszatek i Hetman Koronny Jan Sobieski, ed. D. Milewski (Warszawa: Muzeum Pałacu Króla Jana III w Wilanowie, 2014), pp. 295-316.

KOTLJARCHUK, Andrej. In the Shadows of Poland and Russia. The Grand Duchy of Lithuania and Sweden in the European Crisis of the mid-17th Century (Huddinge: Södertörns högskola, 2006).

MacINNES, Allan. 'The hidden Commonwealth: Poland-Lithuania and Scottish political discourse in the seventeenth century', in: Citizenship and Identity in a Multinational Commonwealth Poland-Lithuania in Context, 1550-1772, eds. K. Friedrich and B. Pendzich (Leyden-Boston: Brill, 2009), pp. 233-26o.

MIERZWA, Edward Alfred. 'Polskie inicjatywy unifikacji europejskiej', in: Polityka i Spoteczeństwo, Vol. 7 (2010), pp. 129-131.

MIRECKA, Martyna. Monarchy as it should be? British perceptions of Poland-Lithuania in the long seventeenth century ( $\mathrm{PhD}$ dissertation, St Andrews University, 2015) http://hdl.handle.net/10023/6o44.

QUELLER, Donald Edward, 'The Development of Ambassadorial Relazioni' in: Renaissance Venice, ed. J.R. Hale (London: Faber and Faber, 1973), pp. 174-196.

RANDALL, David. 'Joseph Mead, Novellante: News, Sociability, and Credibility in Early Stuart England', in: Journal of British Studies, Vol. 45, No 2 (2006), pp. 293-312.

RAYMOND, Joad. 'News', in: The Oxford History of the Popular Print Culture. Cheap Print in Britain and Ireland to 1660, Vol. I, ed. J. Raymond (Oxford, 2011), pp. 377-397.

SLIESORIŪNAS, Gintautas. 'The Image of Lithuania in English Publications in the 17th Century', in: Lithuanian Historical Studies, Vol. 16 (2011), pp. 95-118. 
SOBECKI, Sebastian. 'A New Manuscript of John Peyton's A Relation of the State of Polonia (1599-1619)', in: The Library, 7th series, Vol. 16, No 1 (2015), pp. 80-87.

SOBECKI, Sebastian. 'A man of curious enquiry: John Peyton's Grand Tour to central Europe and Robert Cecil's intelligence network, 1596-16or', in: Renaissance Studies Vol. 29, No 3 (2014), pp. 394-410.

SOBECKI, Sebastian. 'John Peyton's "A Relation of the State of Polonia" and the Accession of King James I, 1598-16o3', in: English Historical Review, Vol. 129, No 540 (2014), pp. 1079-1097.

SPURLOCK, R. Scott. 'Cromwell's Edinburgh Press and the Development of Print Culture in Scotland', in: Scottish Historical Review, Vol. 9o, No 230 (2011), pp. 179-203.

De VIVO, Filippo. 'How to Read Venetian "Relazioni”' in: Renaissance and Reformation, Vol. 34, Nos 1-2 (2011), pp. 25-59.

\section{PER MIGLOTĄ STIKLĄ: LENKIJOS-LIETUVOS UNIJOS REPREZENTACIJOS BRITANIJOJE XVI A. PABAIGOJE IR XVII A.}

Santrauka

\section{ANNA KALINOWSKA}

Šiame straipsnyje apžvelgiami po $1569 \mathrm{~m}$. buvusių Lenkijos ir Lietuvos Didžiosios Kunigaikštystės santykių atspindžiai įvairiuose XVI a. pabaigos-XVII a. Britanijos rašytiniuose šaltiniuose. Čia analizuojami kūriniai parašyti tiek valdovų rūmų aplinkoje, tiek ir jiems dedikuotuose profesionalaus elito sukurtuose veikaluose, taip pat ir kitose tuo metu pasklidusiose publikacijose (knygose ir laikraščiuose), kurios buvo prieinamos plačiajai publikai.

Išnagrinėta medžiaga atskleidžia, kad tie tekstai, kurie cirkuliavo tarp elito ar buvo sukurti žmonių, labiau įsigilinusių i Lenkijos-Lietuvos valstybės specifiką, linko pateikti stipresnę, labiau į Lenkiją orientuotą perspektyvą. Vis dẻlto labai nedaug jų atskleidè praktinę unijos reikšmę. Pavyzdžiui, nuostabu, kad net gausiame Britanijos diplomatų susirašinèjime randama informacija apie uniją yra labai skurdi, nors Johno Peytono (jaunesniojo) parengtas tekstas, dedikuotas karaliui Jamesui VI/I bei jo valstybės sekretoriui, atskleidė nuostabų ryšio tarp dviejų Respublikos dalių paveikslą.

Panaši situacija matyti ir plačiai paplitusiose naujienų spaudiniuose bei knygose, nors ji šiek tiek pagerejjo XVII a. pabaigoje pasirodžius tokiems leidiniams kaip Moseso Pitto The English Atlas ir Bernardo Connoro History of Poland, kuriuose skaitytojams buvo pateikta daugiau kontekstinių duomenų apie Respublikos politinę sistemą. Anksčiausiuose laikraščiuose unijos tema ignoruota ir tik XVII a. antroje pusejje pradèta ją šiek tiek dažniau minèti. 
Yra pakankamai įrodymų, kad Britanijos skaitytojai žinojo apie Lenkijos-Lietuvos valstybę, tačiau pati šalis retai kada buvo pristatoma kiek tiksliau ar išsamiau. Dèl to jie turëjo gana miglotą suvokimą apie praktinį valstybės funkcionavimą. Pavyzdžiui, britų autoriai menkinimo ar net neigè faktą, kad po Liublino unijos Lietuva tapo lygiaverte Lenkijai Respublikos dalimi. Maža to, nedaug rašytojų ar redaktorių apskritai manė, kad jų skaitytojams verta paaiškinti elementariausius unijos veikimo principus ar suteikti įžvalgų apie jos organizacijos funkcionavimą. 